\title{
Triassic Basin Stratigraphy at Grand Manan, New Brunswick, Canada
}

\author{
J. GREGORY MCHONE \\ 9 Dexters Lane, Grand Manan, New Brunswick E5G3A6, Canada \\ <jmchone@nb.sympatico.ca>
}

Date received: 12 April 2011 g Date accepted 26 June 2011

\begin{abstract}
The island of Grand Manan (Canada) in the southwestern Bay of Fundy has the only exposed strata and basalt of the Grand Manan Basin, a mainly submerged Early Mesozoic rift basin about $30 \mathrm{~km}$ wide by $70 \mathrm{~km}$ long. The basin is bounded on the southeast by the west-dipping Red Point Fault, which bisects the island, and on the northwest by a submarine border fault marked by the Murr Escarpment, a bathymetric feature that parallels the coast of Maine (USA). A fault-bounded horst of Ediacaran to Cambrian rocks separates the Grand Manan Basin from the much larger Fundy Basin to the east. The Ashburton Head, Seven Days Work, and Southwest Head members of the endTriassic Dark Harbour Basalt cover most of western Grand Manan with a total thickness around $240 \mathrm{~m}$. Up to $12 \mathrm{~m}$ of sub-horizontal grey mudstone and fine-grained red sandstone of the Dwellys Cove Formation are exposed along the western shoreline beneath the basalt. Coarse red arkosic sandstone a few metres thick at Miller Pond Road rests on a basement of Late Ediacaran rocks east of the basin. Exposures of the Dwellys Cove and Miller Pond Road formations are at the top and bottom, respectively, of several km (?) of sub-horizontal Late Triassic clastic basin strata, juxtaposed by the eastern border fault. Extending from beneath the Miller Pond Road sandstone, a level surface of low relief forms much of the eastern island and its archipelago, which may be interpreted as a relict Late Triassic peneplain that was beneath the Mesozoic strata.
\end{abstract}

\section{RÉSUMÉ}

L'île Grand Manan (Canada) au sud-ouest de la baie de Fundy possède la seule strate et basalte qui affleure du bassin de Grand Manan, un bassin d'effondrement en bonne partie submergé du début du Mésozoïque qui fait environ $30 \mathrm{~km}$ de large sur $70 \mathrm{~km}$ de long. Ce bassin est bordé au sud-est par la faille de Red Point qui présente en pendage vers l'ouest et qui traverse l'île de part en part, et au nord-ouest, par une faille de bordure sous-marine marquée par l'escarpement Murr, une structure bathymétrique qui longe la côte du Maine (É.-U.). Un horst bordé par une faille et composé de roches de la période comprise entre Ediacara et le Cambrien sépare le bassin de Grand Manan du bassin de Fundy, beaucoup plus vaste, à l'est. Les membres de Ashburton Head, de Seven Days Work et de Southwest Head de la formation de basalte de Dark Harbour, de la fin du Trias, recouvrent la plus grande partie de l'ouest de l'île Grand Manan, et leur épaisseur totale serait d'environ $240 \mathrm{~m}$. Des roches de mudstone gris subhorizontal et de grès rouge à grains fins de la Formation de Dwellys Cove dont l'épaisseur peut atteindre $12 \mathrm{~m}$ affleurent le long du rivage occidental, sous le basalte. Une couche de grès arkosique rouge grossier de quelques mètres d'épaisseur sur Miller Pond Road repose sur un socle de roches de la fin d'Ediacara, à l'est du bassin. Des affleurements des Formations de Dwellys Cove et de Miller Pond Road sont observés respectivement au sommet et à la base de la strate subhorizontale de plusieurs kilomètres (?) d'un bassin de roches clastiques de la fin du Trias, en juxtaposition avec la faille de bordure orientale. Sous le grès de Miller Pond Road, une surface de niveau en terrain peu accidenté se prolonge et compose la plus grande portion de la partie est de l'île et de son archipel, ce qui pourrait suggérer la présence d'une ancienne pénéplaine du Trias tardif qui se trouvait sous la strate du Mésozoïque.

[Traduit par la redaction]

\section{INTRODUCTION}

The Mesozoic section on Grand Manan has the only surface exposures of the Grand Manan Basin (Fig. 1), which is herein described as a separate Early Mesozoic rift basin, one of many known along the eastern margin of North America (Olsen 1997). The basin formations are comparable to the better- known clastic and basalt units of the much larger Fundy Basin to the east, which is close enough to share a sedimentary and structural history (Wade et al. 1996).

Unmetamorphosed basalt and clastic sedimentary strata on the island of Grand Manan were recognized as Early Mesozoic, and similar to formations along the western coast of Nova Scotia, in descriptions by Chapman (1870), Powers (1916), Alcock 


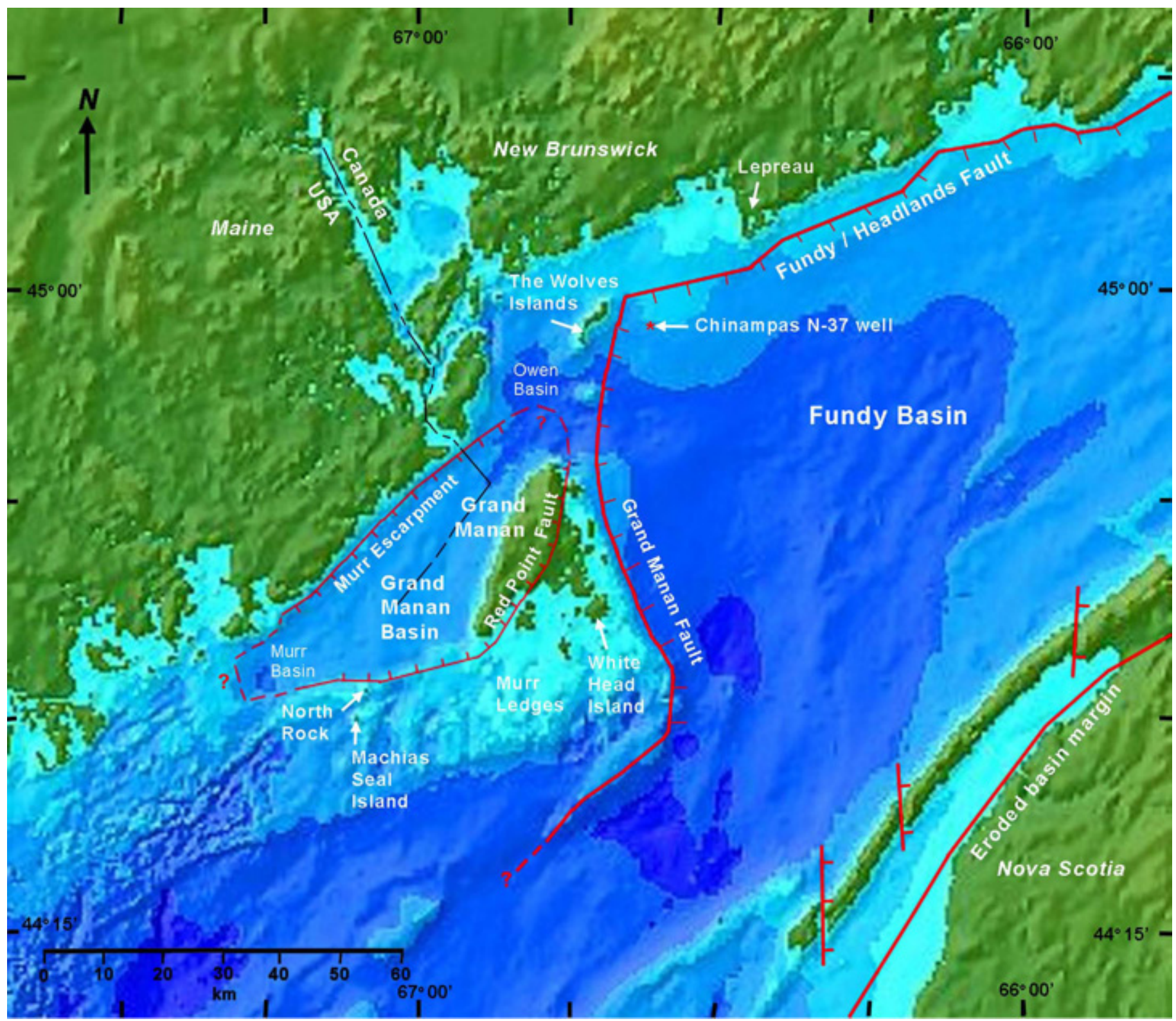

Fig. 1. Digital bathymetry of the Grand Manan Basin area and topography of surrounding land areas. The coloured relief base map is by Roworth and Signell (1998), with structural borders in red after Wade et al.(1996) and this paper. Line hachures indicate down-dip offset directions on normal faults. The darkest blue colour indicates where water depths exceed $125 \mathrm{~m}$, with lighter colours nearer the surface. Shaded green colours simulate land relief.

(1948), Patrick (1964), Wade and Jansa (1994), and McHone (2001). A generalized map by George Pajari and colleagues is shown in Allaby (1984, p. 42) and in a report for the Village of Grand Manan (Hart and Pajari 1988). The island's current open-file bedrock map by Fyffe and Grant (2005) shows little detail for the Mesozoic formations and structures, but an updated version is in preparation (Fyffe et al. 2011).

This paper provides brief field descriptions of the Early Mesozoic formations of Grand Manan, with an overview of their stratigraphic relationships and structural history. The juxtaposition of the top and bottom few metres of the sub-basalt sedimentary section on opposite sides of the island is a unique and unexpected occurrence, and it indicates displacement on the eastern border fault that coincides with the total thickness of the sedimentary Triassic strata.

\section{THE GRAND MANAN BASIN}

The Grand Manan Basin is a small Early Mesozoic rift basin with maximum dimensions around $30 \mathrm{~km}$ wide by $70 \mathrm{~km}$ long (approximately $1300 \mathrm{~km}^{2}$ ), with its western margin about a km offshore and parallel to the easternmost coast of Maine (Fig. 1). The international boundary between Canada and the United States extends through the central part of the basin, but the border remains unresolved around Machias Seal Island a few 


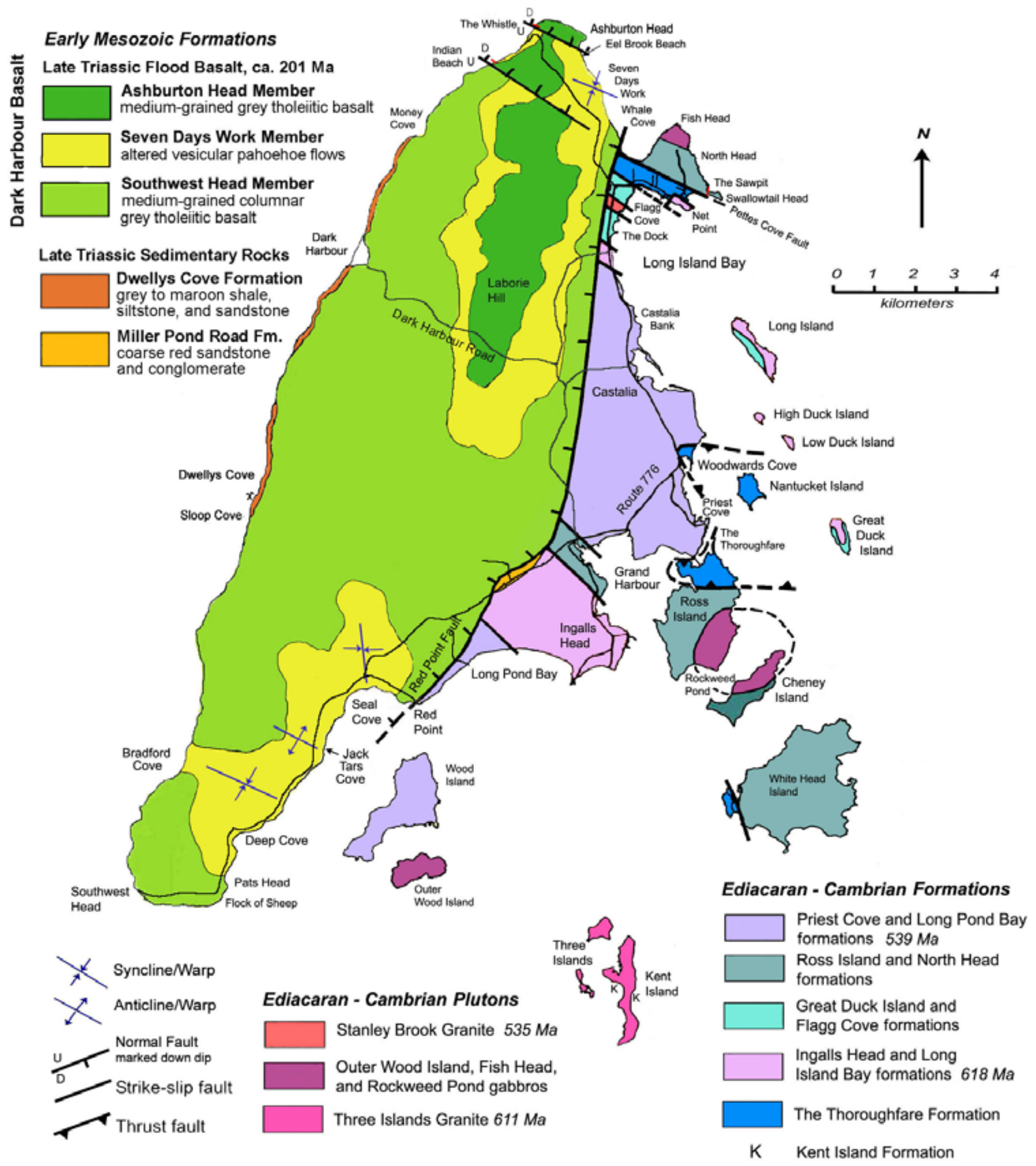

Fig. 2. Bedrock geology map of Grand Manan, simplified from Fyffe et al. (2011). 
$\mathrm{km}$ to the south (Fig. 1). The western basin margin is well defined by the Murr Escarpment, a straight and steep bathymetric slope close to the Maine coast that apparently marks a highangle Mesozoic border fault (Barnhardt et al. 1996; Dickson et al. 1994). The eastern basin border is located at the Red Point Fault on Grand Manan, which continues along a sharp break in the bathymetric topography offshore to the south (Fig. 1). The ends of the basin to the southwest and northeast are not accurately defined but are limited by bathymetric relief to the southwest, and by a seismic line across the Owen basin south of The Wolves islands that shows no Mesozoic strata (Fig. 2 of Wade et al. 1996). Seismic survey lines reported by Tagg and Uchupi (1964) and Dickson et al. (1994) crossed the southwestern end of the Grand Manan Basin and indicate Mesozoic strata, but little about the basement structures.

Barnhardt et al. (1996) and Dickson et al. (1994) showed that the basin has a remarkably level and low-relief bathymetric depth around 70 to $90 \mathrm{~m}$. The basalt flows and sedimentary strata on Grand Manan are generally within a few degrees of horizontal, but with limited areas of wide gentle folds and a few normal faults. The sub-horizontal strata are an exception to the general description of Early Mesozoic rift basins in eastern North America, which tend to be half-grabens with strata that dip toward one major border fault (Olsen 1997). The indication for the Grand Manan Basin is that its western and eastern border faults have similar vertical displacements, and perhaps moved simultaneously.

The most detailed thickness information for strata that might also represent the Grand Manan Basin is reported in a log for the Mobil Gulf Chinampas N-37 deep exploration well drilled east of The Wolves, within the western Fundy Basin north of Grand Manan (Fig. 1). As reported in Wade et al. (1996), the well encountered from top to bottom: $357 \mathrm{~m}$ of McCoy Brook shale and siltstone; $333 \mathrm{~m}$ of North Mountain basalt; $1157 \mathrm{~m}$ of Blomidon sandstone; and $1718+\mathrm{m}$ of Wolfville sandstone (not completely penetrated). The uppermost part of the basalt and any strata formerly above it on Grand Manan are not present or were eroded away. These formation thicknesses vary greatly across the Fundy Basin, and the Chinampas N-37 well can only be used for a rough estimate of formation thicknesses expected within the Grand Manan Basin.

Machias Seal Island to the south of the Grand Manan Basin is a plutonic exposure of quartz monzodiorite, which yielded an Early Cambrian U-Pb (zircon) age of $542.0 \pm 0.9 \mathrm{Ma}$ (Barr et al.2010). The adjacent mainland and other islands are comprised of Paleozoic and Late Proterozoic metamorphic rocks of the Ellsworth, Mascarene, New River, Brookville, and Kingston terranes (Black et al. 2004) as well as Late Paleozoic granitic plutons (McLeod et al. 1994).

\section{The Fundy Basin}

Late Triassic to Early Jurassic sedimentary and volcanic formations of the Fundy Basin are well exposed along the western shorelines of Nova Scotia (Greenough 1995; Olsen 1997; Kontak 2008) and can be studied from seismic surveys for much of the Bay of Fundy (Wade et al. 1996). Up to $8000 \mathrm{~m}$ of clastic sediments and $1000 \mathrm{~m}$ of basalt fill the central Fundy Basin, thinning to less than half that eastward into Nova Scotia (Fig. 3). In western Nova Scotia the Fundy strata generally dip around $10^{\circ}-15^{\circ}$ to the northwest, due to normal faulting in the western part of the basin as well as subsidence toward southcentral areas (Wade et al. 1996). In contrast, the sedimentary strata and lower basalt flows on Grand Manan are generally within $5^{\circ}$ of horizontal except near faults, and with broad, gently dipping synclines and anticlines across the island (Fig. 2).

A large north-south basement fault block includes the eastern third of Grand Manan and its entire associated "archipelago" of smaller islands. This "White Head Island horst" is bound on its eastern side by the submerged Grand Manan Fault, which lies within the Bay of Fundy and provides a southwestern border for the larger Fundy Basin (Fig. 1). The western border of the basement horst is the partially exposed Red Point Fault (Fig. 2), which is also the eastern border fault of the Grand Manan Basin.

Because the Mesozoic strata and basalt of the Grand Manan Basin are physically separate from formations of the Fundy Basin, new basin formation names are proposed (Fig. 2 and following sections). Grand Manan metamorphic formations are also separated from similar formations elsewhere and have been subject to revision with new work by Fyffe and Grant (2001, 2005), Black et al. (2004), and Miller et al. (2007). Relating tectonic terranes to the metamorphic basement rocks of Grand Manan has been problematic, but field work and radiometric dates of 618 to 539 Ma suggest correlation with the New River and Mascarene terranes of New Brunswick (Miller et al. 2007). Unlike the older rocks, the Mesozoic formations are directly comparable between the Grand Manan and Fundy Basins (Fig. 3), and they may have been contiguous before tectonic activity and erosion created the present map patterns. Discussions of related "broad terrane" vs. "closed basin" models have been presented by McHone (1996), Wade et al. (1996), Olsen (1997), Pe-Piper and Piper (1999), and McHone and Puffer (2003), among others, and a related model for the Grand Manan Basin will be developed in further work on tectonic structures and basalts.

As described in more detail in the following sections, up to $12 \mathrm{~m}$ of mudstone and fine-grained sandstone of the hereinnamed Dwellys Cove Formation underlie the Dark Harbour Basalt along much of the western shoreline, while a few metres of Triassic sandstone in a poorly defined area at Miller Pond Road lie directly on metamorphic basement east of the Red Point Fault (Fig. 2). The Dwellys Cove outcrops must be close to the age of the basalt, but if the Miller Pond Road sandstone exposures represent the base of the section, those rocks may be 15 to 20 million years older in the Norian age of the earliest basin sedimentation (Olsen 1997).

\section{Dark Harbour Basalt}

Mesozoic exposures on western Grand Manan are dominated by the herein-named Dark Harbour Basalt. Although the 


\section{Mesozoic Stratigraphy and Cross Section, Southwestern Bay of Fundy}

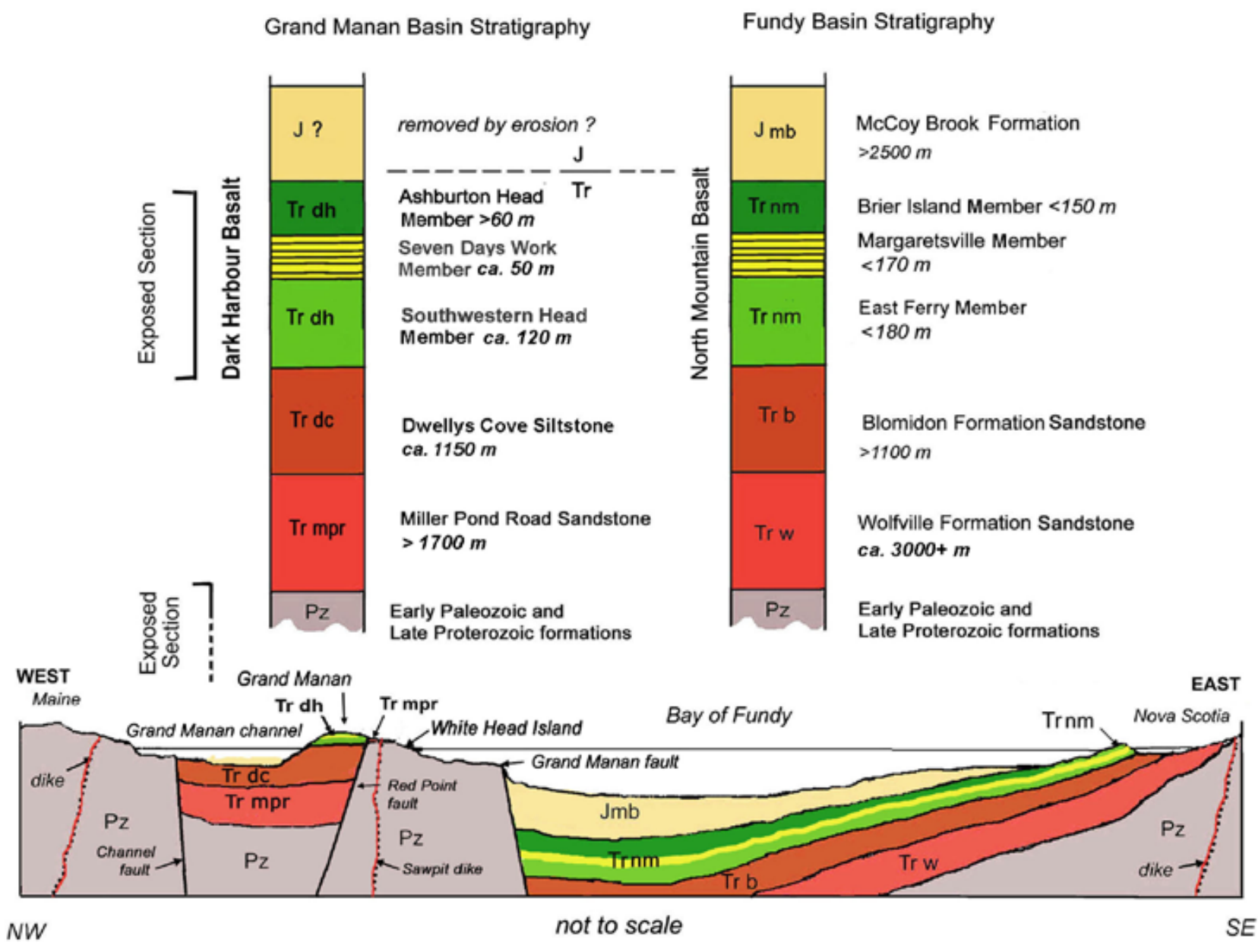

Fig. 3. Correlation and conceptual cross section sketch of Mesozoic formations of the Grand Manan Basin and Fundy Basin (ref. this paper; Wade et al. 1996). Strata thicknesses for Grand Manan are estimated from the Chinampas N-37 well log while Fundy Basin strata are maximum estimates, both from Wade et al. (1996).

basalt characterizes much of Grand Manan, the name "Grand Manan" has already been used for a group of Late Neoproterozoic formations on the eastern side (Fyffe and Grant 2001). However, the basalt formation is well represented by easily accessed outcrops of its three members along the road to Dark Harbour on the western coast of the island, and thus the name assignment.

The basalt has three members, which from top to bottom are: Ashburton Head Member (> $80 \mathrm{~m}$ ), Seven Days Work Member (ca. $50 \mathrm{~m}$ ) and Southwest Head Member (ca. 110 $\mathrm{m})$. Their petrology is similar to, and they are probably comagmatic with, the Brier Island, Margaretsville, and East Ferry members of the North Mountain Basalt in Nova Scotia (Fig. 3 ) described by Kontak (2008). Additional descriptions of this basalt were made by Greenough (1995), who pointed out that this is one of the largest lava flows known, with an estimated $6,600 \mathrm{~km}^{3}$ present within the Fundy basin. The significance of a U-Pb zircon date of $201.27 \pm 0.06 \mathrm{Ma}$ (Schoene et al. 2006) for the East Ferry member was discussed by Schaltegger $e$ t al. (2008), and after several decades in which it was assigned to the start of Early Jurassic, the North Mountain Basalt has been shown to be end-Triassic in age (Cirilli et al. 2009). The age assignments invite a cause and effect relationship of this volcanic event with the great Triassic-Jurassic mass extinction(Deenen et al. 2010).

The Southwest Head Member at Southwest Head is about $110 \mathrm{~m}$ thick and displays a colonnade or columnar structure through its entire thickness, much like in a dyke or sill (e.g., Palisades Sill) and without the expected entablature of contorted joints. About 10 to $15 \mathrm{~m}$ below the top of the Southwest Head Member, a series of coarse segregation sheets or intrusional layers of pegmatitic pyroxene and plagioclase crystals occurs near Whale Cove and Red Point. Philpotts et al. (1996) described the sheets as late-stage liquids squeezed upwards from a crystal mush of partially solidified basalt. The presence of segregation 
sheets is a useful indicator of the location within the Southwest Head Member relative to its top and bottom.

The lava lake represented by the Southwest Head Member was sandwiched between a base of relatively dry lakebed and a thick sequence of cooled lava flows of the Seven Days Work Member over it, so the basaltic liquid cooled slowly and uniformly. A more detailed model for the emplacement of the basalt and its volcanic structures is a work in progress.

A relatively level contact between the Southwest Head Member and underlying sedimentary Dwellys Cove Formation is exposed in a long section of the western shoreline (Fig. 2). Most measurements of bedding and the contact show very modest dip angles, with less than $5^{\circ}$ west near Dark Harbour and a few degrees southeast near Dwellys Cove. A few small hills and valleys in the contact probably reflect original surface features of the silt and sand that were covered by the initial lava.

Overlying the Southwest Head Member are approximately 12 to 14 vesicular lava flows, each a few metres thick, which form the Seven Days Work Member (Fig. 4). The member is named after a nearly complete section that occurs along the shoreline referred to as Seven Days Work, northwest of Whale Cove. Small structures in this member include pinch and swell of flows, pahoehoe lava tongues, injections of narrow dykes and sills, erosional unconformities, rubble tops and glassy contacts, gaseous pipe vesicles, lava tubes and caves, and tumulus structures.

The boundary between the top of the Southwest Head Member and overlying Seven Days Work lava flows is conformable but not horizontal where it is observed on the limbs of domes, synclines, and anticlines, which extend a few tens of metres to a kilometre or more wide (Fig. 2). The limbs of these structures dip from $10^{\circ}-30^{\circ}$ toward or away from the fold axes. This deformation is not observed along the contact with underlying sedimentary strata, which suggests that the lower Southwest Head Member was still mostly in a liquid state when the Seven Days Work Member lavas flowed over or onto it, forming a thick, layered crust on this giant lava lake within the original rift basin. Sags, domes, ridges, and other deformation features occur in these surficial lava layers, possibly from thickness variations as well as from magmatic pressure and intrusions from below. Additional instabilities resulted from density differences in the upper part of the lava lake caused by concentrations of rising gas bubbles, which led to breakouts or dykes of vesicular basalt, and lava flows from those local sources.

A conformable contact between the Seven Days Work Member and overlying Ashburton Head Member is gently dipping at its only observed location at Indian Beach (Fig. 5). The Ashburton Head Member is interpreted to be a final and very thick lava flow, which is co-magmatic but caps the entire volcanic sequence in the basin. At the type locality of Ashburton Head it is at least $60 \mathrm{~m}$ thick, with any higher levels and overlying formations probably removed by erosion. The basalt is columnar but commonly deformed.

Several normal faults with significant displacements have been observed in shoreline cliffs, particularly in the northern part of the island (Fig 2). Ashburton Head is bound by a rela-

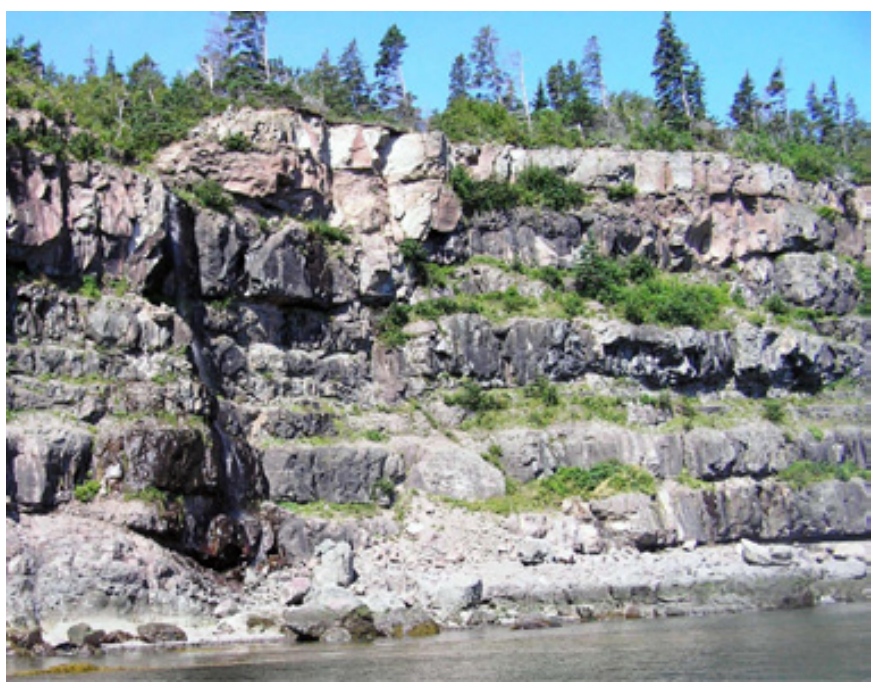

Fig. 4. The Seven Days Work Member of the Dark Harbour Basalt at the type locality northwest of Whale Cove. Vegetation marks rubble tops or paleo-regoliths between individual lava flows. The cliff face is about $50 \mathrm{~m}$ high.

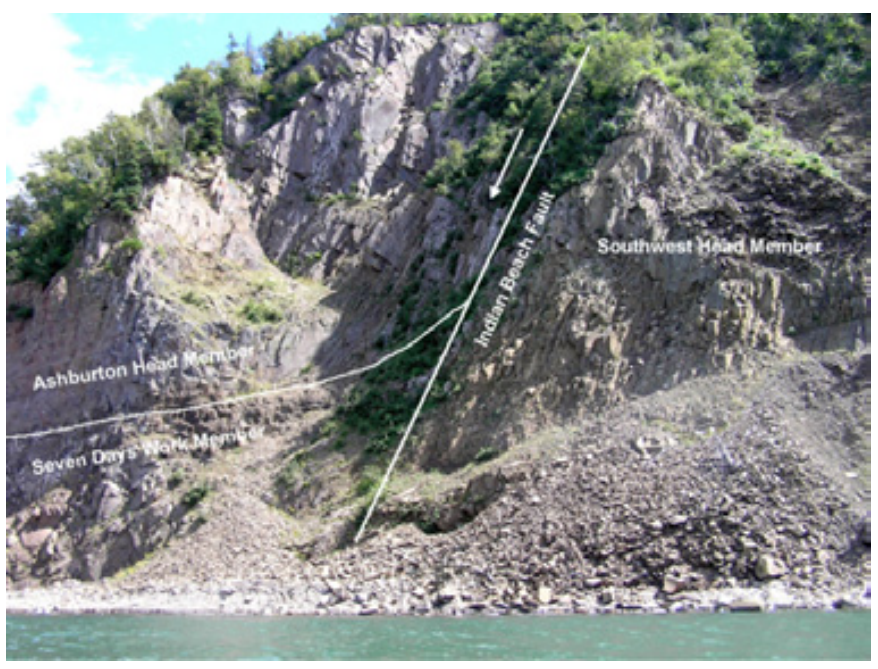

Fig. 5. A high-angle fault under the vegetation in this cliff face at Indian Beach separating lower Southwest Head Member (right side) from Seven Days Work (layered flows, lower left) and upper Ashburton Head (upper left) members of the Dark Harbour Basalt. The vertical offset is approximately $120 \mathrm{~m}$ based on positions of the basalt members. The steep joints are roughly parallel to the fault. The cliff face is about $80 \mathrm{~m}$ high, looking northeast.

tively shallow, northeast-dipping normal fault, exposed on beaches at either end, along which the Ashburton Head Member was dropped down against the Seven Days Work Member. A steeper normal fault trends east-southeast from Indian Beach, where it juxtaposes the Southwest Head Member basalt to the south against Seven Days Work and Ashburton Head members to the north (Fig. 5). Interestingly, this fault is roughly co-linear with the Oak Bay Fault on the mainland to the west, and 
possibly with a fault near Pettes Cove on the eastern shore of Grand Manan (Fyffe and Grant 2001, 2005); however, inland exposures are too poor to trace it across the island.

The Red Point Fault creates a major topographic and geological division on Grand Manan between Red Point and Whale Cove (Fig. 2), with a higher hilly and bog-rich upland underlain by Triassic basalt to the west, and a relatively low and level landscape underlain by Ediacaran to Cambrian rocks to the east. A fault-line scarp marks its location through much of the island, but the fault is only exposed at Red Point (Fig. 6). Basalt of the Southwest Head Member (within $15 \mathrm{~m}$ of its top as indicated by segregation sheets) is drag-folded against red argillite or meta-volcaniclastic siltstone of the Cambrian (?) Long Pond Bay Formation (Fyffe and Grant 2005). The Red Point Fault dips about $50^{\circ}$ to the west-northwest, and the shallow angle means that the map trace of the fault must bend west or east where it intersects lower and higher surface elevations. Basalt columns that are nearly vertical about $20 \mathrm{~m}$ west of the fault become fractured and bent to a shallow angle as the fault is approached, consistent with drag downward along the fault surface (Fig. 6). Brecciated basalt is also present in several narrow zones along the cliff face to the west. As described in following sections, the vertical displacement along the fault apparently matches the total thickness of sedimentary strata beneath the basalt, which is estimated at ca. $3 \mathrm{~km}$. The low fault angle also requires displacement of the basin strata of 2-3 km westward, assuming mainly post-depositional tectonism.

\section{Dwellys Cove Formation}

This formation is named after Dwellys Cove on the southwestern shoreline of Grand Manan (Fig 2), where about $8 \mathrm{~m}$ of mudstone, siltstone, and fine-grained sandstone are exposed directly beneath the Southwest Head Member basalt. The formation occurs along about $14 \mathrm{~km}$ of the western shoreline, with the northern end at Money Cove Head where approximately 5 $m$ is exposed, but the contact is not present beneath the basalt cliffs of the shorelines on the north side of the cove. The contact and Dwellys Cove Formation are well exposed southward along the shoreline, except in places of talus cover and for a section about $1 \mathrm{~km}$ long south of Little Dark Harbour. The contact gradually lowers to below sea level near The Ladders between Dwellys Cove and Sloop Cove (Fig. 2) and it has not been observed farther south.

A locally famous mine adit was cut into siltstone of the Dwellys Cove Formation in a prospect for copper in 1870 (near Fig. 7). A report by E. J. Chapman (1870) for the exploration group of his time describes the formation as mainly "buff colored sandstone" but with 7 or 8 feet (ca. $2.5 \mathrm{~m}$ ) of soft palecolored copper-bearing "tufa" directly beneath the basalt. The mine location was known as Sloop Cove, but more recent maps locate Sloop Cove about a km farther south, where no subbasalt strata are exposed. Because Dwellys Cove is close and has a good exposure of these strata, Dwellys Cove Formation is a more appropriate name. Although there are blue-green stains and minor chalcocite close to the contact with the basalt,

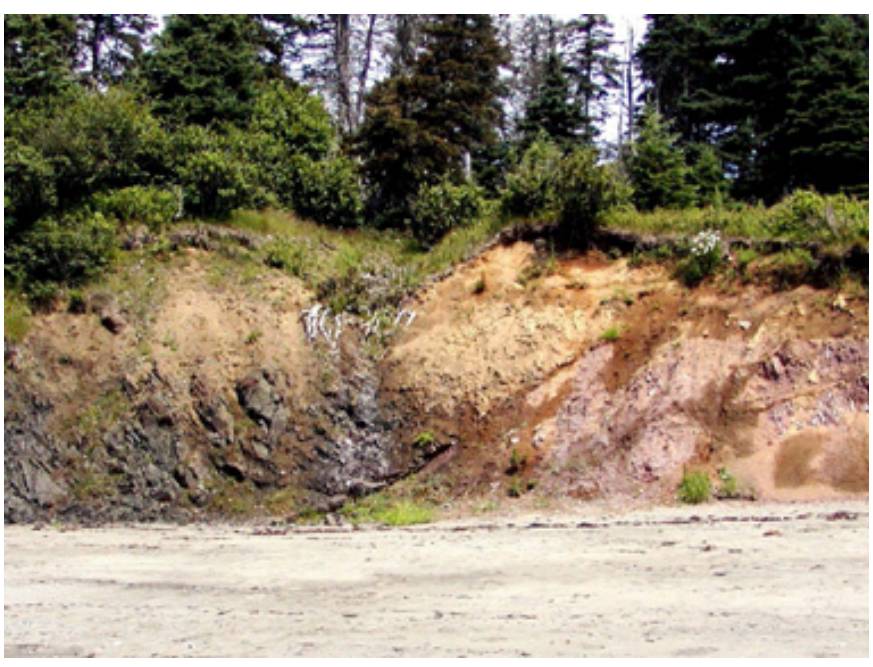

Fig. 6. The basin border fault at Red Point, looking north. Late Triassic columnar basalt of the Southwest Head Member of the Dark Harbour Basalt has moved downward on the left against Cambrian (?) argillite of the Long Pond Bay formation on the right.

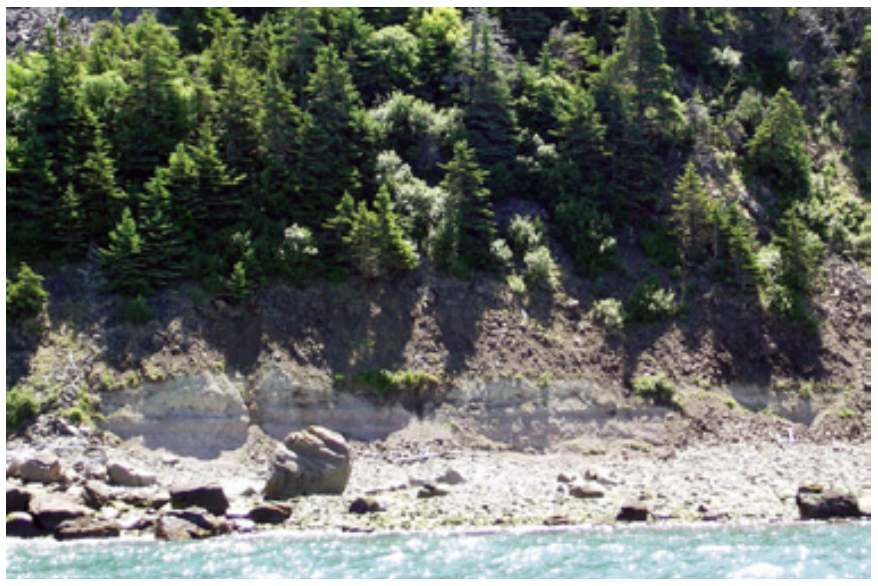

Fig. 7. Fine-grained maroon sandstone in a bank about $4 \mathrm{~m}$ high underlies $\mathrm{Cu}$-stained horizons of grey to buff siltstone at Dwellys Cove, near the "Sloop Cove Mine." The contact with overlying Dark Harbour Basalt is mostly covered by talus at this location.

very little copper was probably found in 1870 and certainly in a later exploration program by the Keevil Mining Group Ltd. (Patrick 1964). Part of one core from the Keevil program is on display at the Grand Manan Museum in Grand Harbour, where it illustrates the major lithologies down to 660 feet $(201 \mathrm{~m})$.

The Keevil Mining Group exploration program for copper in the Dwellys Cove Formation (unnamed by the program) had a report by Patrick (1964) with this description on pp. 4-5: "Underlying the basalt is a series of clastic sedimentary rocks ranging from coarse sandstone to shale and mudstone with intermittent gypsum bearing horizons and veins, beds, blebs and cavity fillings of acicular white sellenite. The sedimentary rocks observed in outcrop consist of the top 30 to 
40 feet of what is apparently a considerable thickness of Triassic sediments underlying the Bay of Fundy. The deepest drill hole gave a continuous section of some 380 feet of sediments which are mainly red sandstone with some greenish coloured members and red and green shale and mudstone near the top of the sequence. The upper most 20 feet of the sedimentary sequence is cupriferous and was the main object of the exploration program."

Their comprehensive program of sampling, coring, and petrochemical analyses showed only minor copper in thin zones that were too low-grade to warrant further work.

Easier access to the Dwellys Cove Formation can be made along the cobble beach north from Dark Harbour, where alternating layers of pale grey siltstone and maroon clay-rich shaley mudstone 10 to $50 \mathrm{~cm}$ thick (Fig. 8) appear to reflect Milankovitch climate cycles as discussed by Olsen (1997). The mudstone has numerous pits and spots with remnants of light-colored evaporite minerals, including gypsum. The contact with the basalt is about $7 \mathrm{~m}$ higher in this location, where a soft dusty

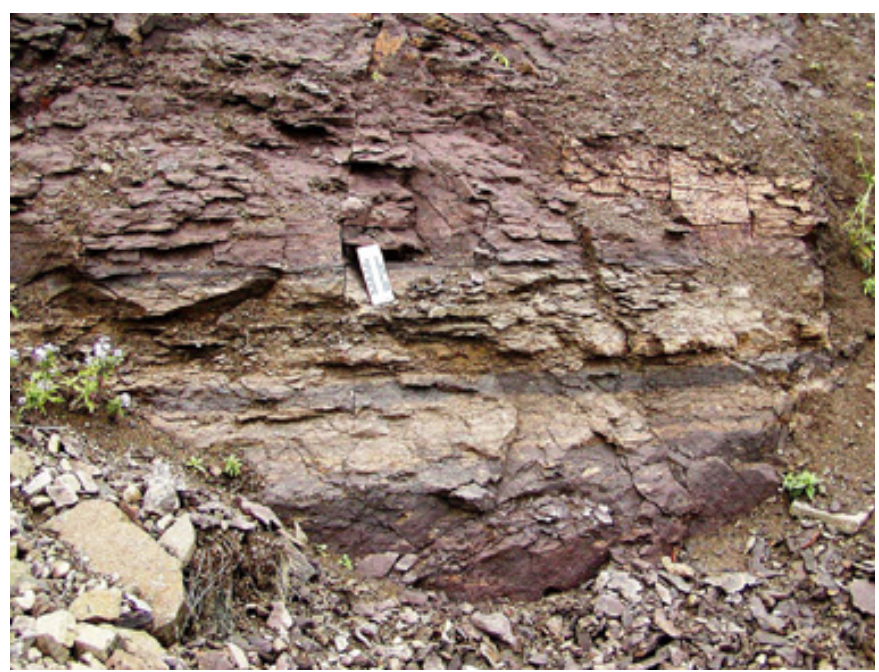

Fig. 8. Alternating layers of siltstone and clay-rich mudstone of the Dwellys Cove Formation north of Dark Harbour. The scale bar is 6 inches $/ 15 \mathrm{~cm}$.

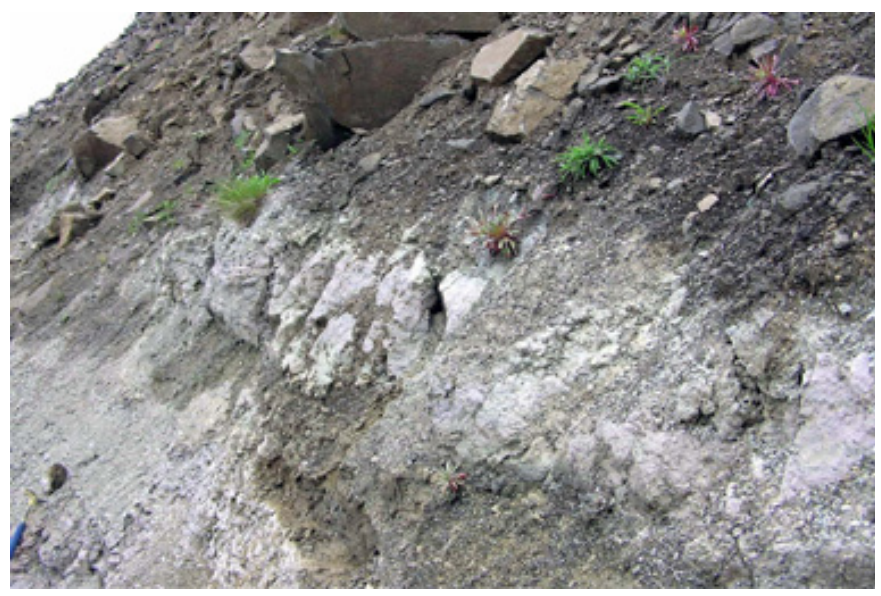

Fig. 9. Bleached zone beneath basalt north of Dark Harbour. Note the hammer, lower left. pale grey mudstone shows $\mathrm{cm}$-thin bands of blue $\mathrm{Cu}$-mineral stains (azurite?), capping an off-white or bleached $40-80 \mathrm{~cm}$ thick zone that is harder (indurated), apparently as a hydrothermal effect under the basalt (Fig. 9). Similar bleached sediment zones are noted beneath basalt elsewhere in the Fundy Basin and other rift basins, presumably due to reduction of iron oxides in the clastic matrix.

The clay-rich mudstone is mainly confined to the uppermost 8 to $10 \mathrm{~m}$ of the Dwellys Cove Formation, and it is informally referred to in this paper as the contact member. It might be produced by a local playa or ephemeral lake in a semi-arid climate, as in the sedimentary environment described by Mertz and Hubert (1990) for the Blomidon Formation. Wade and Jansa (1994, p. 228) reported that this lithology is not known in the Blomidon Formation beneath the basalt elsewhere around the Bay of Fundy. However, similar banded mudstone is present for a few meters beneath North Mountain Basalt at Partridge Island in Nova Scotia (Olsen and Et-Touhami 2008), who include a horizon in it that marks the end-Triassic mass extinction.

More common in the Blomidon Formation is "redbed" sandstone (Mertz and Hubert 1990). This appears to be true for the Dwellys Cove Formation as well, and light red, finegrained sandstone makes up most of the clastic part of the core on display in the Grand Manan Museum, which is missing the clay-rich contact member directly beneath the basalt. Core logs for 9 wells in the program reported by Patrick (1964) have a maximum well depth through $181 \mathrm{ft}(55.1 \mathrm{~m})$ of arenaceous "brick-red" to mottled-colour sandstone beneath the contact member, which has 15-35 ft (4.6-10.7 m) of grey to red (maroon) argillaceous siltstone and shale.

The author found an exposure of similar red, fine-grained arenaceous sandstone in a near-shore pavement about $1 \mathrm{~km}$ north of Dark Harbour (Fig. 10), where it occurs about $12 \mathrm{~m}$

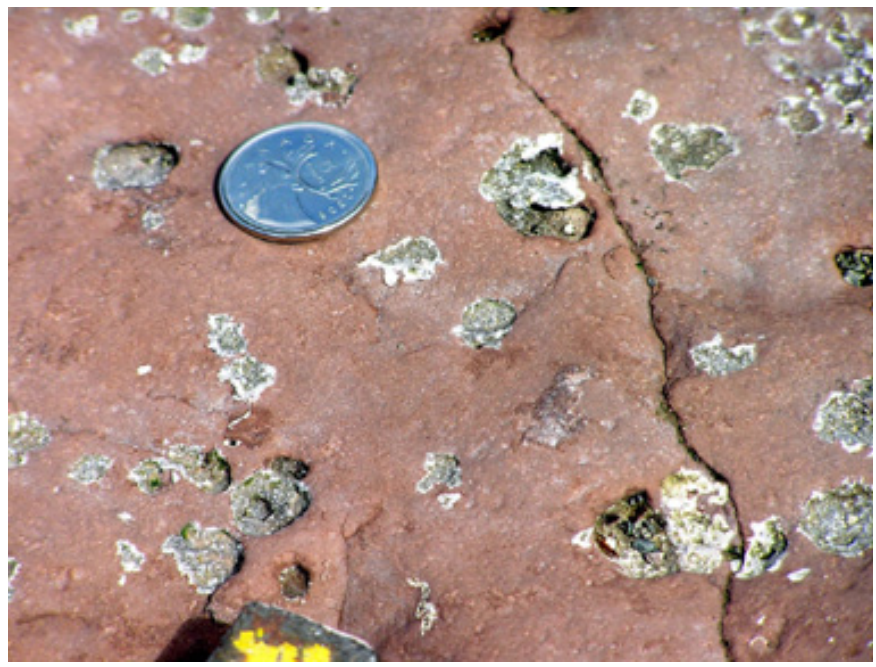

Fig. 10. Evaporite mineral patches and eroded vugs in the bedding surface of fine-grained, brick-red sandstone of the Dwellys Cove Formation north of Dark Harbour. The coin has a diameter of $23 \mathrm{~mm}$. The end of a hammer appears at the bottom of the photo. 
beneath the contact with the basalt. The bedding surface dips about $5^{\circ}$ westward (seaward), which might be the reason the overlying basalt is relatively unstable, as its columns are perpendicular to the bedding and thus tilt outward from the cliff face. Patches and holes in the bedding surface are related to evaporite minerals (Fig. 10), similar to mineral patches in the mudstone of the contact member. An unidentified green mineral occurs with the gypsum (Fig. 10). Minerals that have been eroded to form the open spaces are also unidentified but may be described in other studies of the Blomidon Formation (Mertz and Hubert 1990; Olsen and Et-Touhami 2008).

\section{Miller Pond Road Formation}

Alcock(1948) noted the presence of "minor amounts of reddish and brownish sandstone and conglomerate" a few km to the southwest of Grand Harbour, which he mapped beneath the basalt along the western side of the Red Point Fault. Alcock apparently did not see the distinctly different Dwellys Cove siltstone beneath basalt, as his map shows none along the western shoreline. Wade et al. (1996 p. 213) mentioned that they looked for, but did not find Alcock's eastern sandstone. The map by Fyffe and Grant (2005) reproduces the same outcrop area shown by Alcock (1948). This sandstone was relocated by the author in the spring of 2010 (Fig. 11), exposed partly under brush along a bank on the southeastern side of an abandoned gravel quarry off Miller Pond Road, and within the area where it was originally mapped (Fig. 2).

The purplish red quartz arenite is medium to coarse grained, tending to arkosic with up to $10 \%$ feldspar grains, a trace of clay in the matrix, and weakly cemented by iron oxide and calcite. Bedding is difficult to discern but appears to dip about 5-10 toward the northeast. The sandstone at the northern end of the bank lacks foreign rock fragments, but a few meters toward the south it contains scattered clasts (Fig. 11) of grey-green to rusty phyllitic quartzite or meta-volcaniclastic siltstone similar to the major lithology of the Ingalls Head Formation to the east (Fig. 2). The clasts are angular and range around $0.2-4.0 \mathrm{~cm}$ in length. This phyllite appears to be the only clast lithology present in the Miller Pond Road sandstone.

Outcrops in the bank about $10 \mathrm{~m}$ to the southwest are downdip, and thus a meter or so stratigraphically below the level of the conglomeratic sandstone outcrop. Here the sandstone grades into a mass of angular pieces of the same phyllite, becoming the matrix of clast-supported breccia or paleo-regolith (Fig. 12). The angular fragments preserve a fabric or preferred orientation that might represent original cleavage or foliation in the bedrock, which appears to be dipping toward the north more steeply than the sandstone bedding.

The field evidence indicates that the sandstone was deposited upon and grades into the top of the Ingalls Head Formation, although solid bedrock of this basement rock is not locally exposed. Surface exposures of some metamorphic basement rocks are observed to be brecciated into present-day angular gravel at other locations, apparently a function of rock cleavage and fracture patterns. The exact appearance of the unconfor-

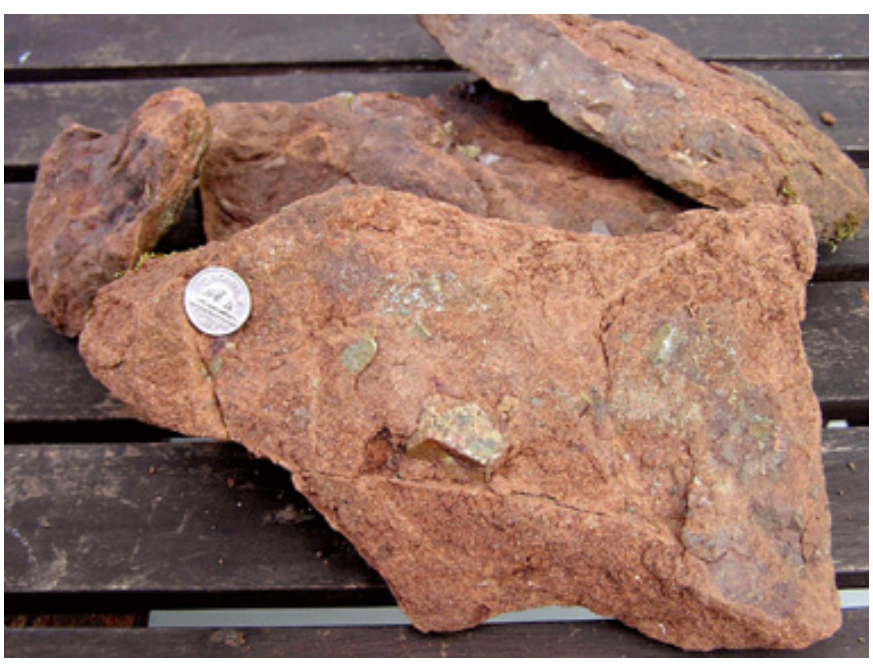

Fig. 11. Feldspar-bearing red arenaceous sandstone with scattered clasts of grey-green phyllite from an abandoned gravel quarry near Miller Pond Road. The coin has a diameter of $21 \mathrm{~mm}$.

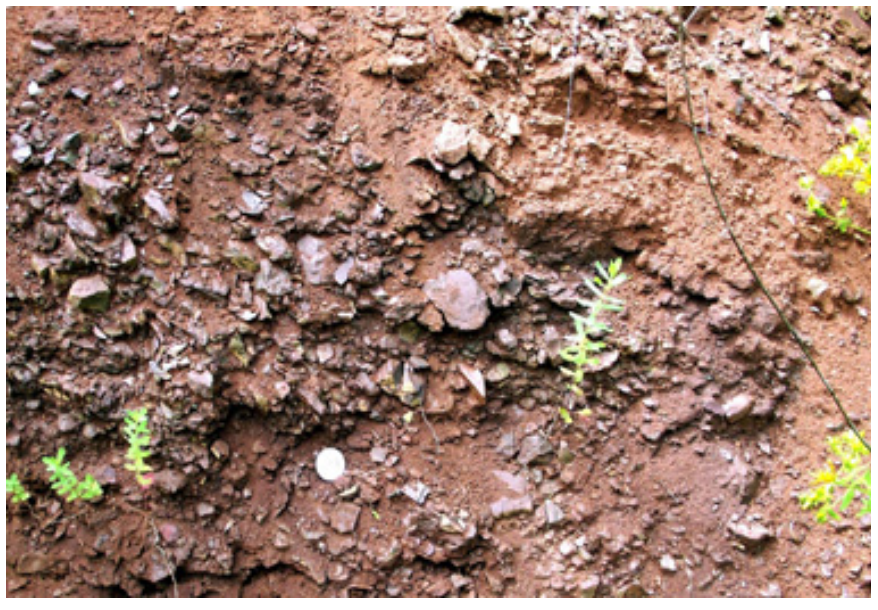

Fig. 12. Unconsolidated clast-supported phyllite breccia of the Ingalls Head Formation grades toward the upper right into pebbly red sandstone of the Miller Pond Road Formation. The diameter of the coin is $23 \mathrm{~mm}$.

mity at this location is obscured by vegetation and the intermixing of the formations in a paleo-regolith.

Columnar basalt of the Southwest Head Member crops out in the hillside about $70 \mathrm{~m}$ to the northwest, just outside the level grounds of the gravel quarry. The Red Point Fault apparently is located near the base of the hillside, requiring the sandstone to be east of the fault and not beneath the basalt as shown by Alcock (1948) and Fyffe and Grant (2005). The sandstone does not resemble a basin margin alluvial conglomerate or fanglomerate, which would typically contain a mix of rounded clasts of durable lithologies derived from adjacent highlands. This exposure of Miller Pond Road sandstone is interpreted to be the bottom of the Triassic stratigraphic section beneath the basalt, not originally adjacent to the basalt or fault-bounded basement rocks, and it is preserved on the White Head Island horst as a 
remnant equivalent to the base of the Wolfville Formation of the Fundy Basin (Fig. 3).

Because the top of the island's sedimentary section is exposed at only a slightly lower elevation along the shoreline to the west, and the strata are relatively horizontal, the vertical offset of the basin border fault must coincide by remarkable chance with the total thickness of the Triassic sedimentary section. As discussed earlier, sub-basalt strata totals around 2850 $\mathrm{m}$ in the Mobil Gulf Chinampas N-37 exploration well to the north of Grand Manan (Wade et al. 1996), which provides an estimate for the Grand Manan Triassic section and border fault offset.

\section{Topographic Features}

East of the Red Point Fault, the metamorphic basement rocks of Grand Manan have a generally low and level surface of less than $30 \mathrm{~m}$ elevation (except north of the Pettes Cove Fault), with shallow harbours and low islands off shore (Fig. 13). This gentle topography has been much more suitable for small-boat harbours, farms, and residential areas than the hilly uplands of Grand Manan west of the fault, where there are many bogs and steep basalt ledges.

The contrasting topography is shown on a digital relief map (Fig. 14), and it is not consistent with differential erosion that might be expected to develop from the variety of lithologies and structures of eastern Grand Manan. Coastal areas of the adjacent mainlands of Maine and New Brunswick are generally more rugged, with $10-40 \mathrm{~m}$ headlands of wave-cut cliffs and drowned valleys (Dickson et al. 1994; Wade et al. 1996, p. 197). Those areas are west of the Grand Manan and Fundy rift basins, whereas eastern Grand Manan is an exposed part of the White Head Island basement horst between the basins (Figs. 1, 2, and 3).

\section{DISCUSSION}

An explanation of why the eastern topography is so level is provided by the presence of the Triassic sediment at Miller Pond Road. This sediment is interpreted to be the base of the strata that eventually filled the Grand Manan and Fundy rift basins, starting around $215 \mathrm{Ma}$ (Olsen 1997). Because it is only weakly cemented, the sandstone must have poor resistance to erosion, and the area of the sandstone is not lower or much better protected than other areas of the eastern island. It is proposed that the Miller Pond Road sandstone exposure is the last remnant of several $\mathrm{km}$ of Triassic basin formations that originally covered the present level metamorphic surface of eastern Grand Manan, possibly up to relatively recent times.

In that case, much of the modern topography of eastern Grand Manan was developed during the pre-Late Triassic Period, and it now represents a paleo-peneplain, or the same surface upon which the Mesozoic basin sediments first started to collect around $215 \mathrm{Ma}$. In this model, normal faulting created the horst in the Jurassic Period, and regional uplift since the

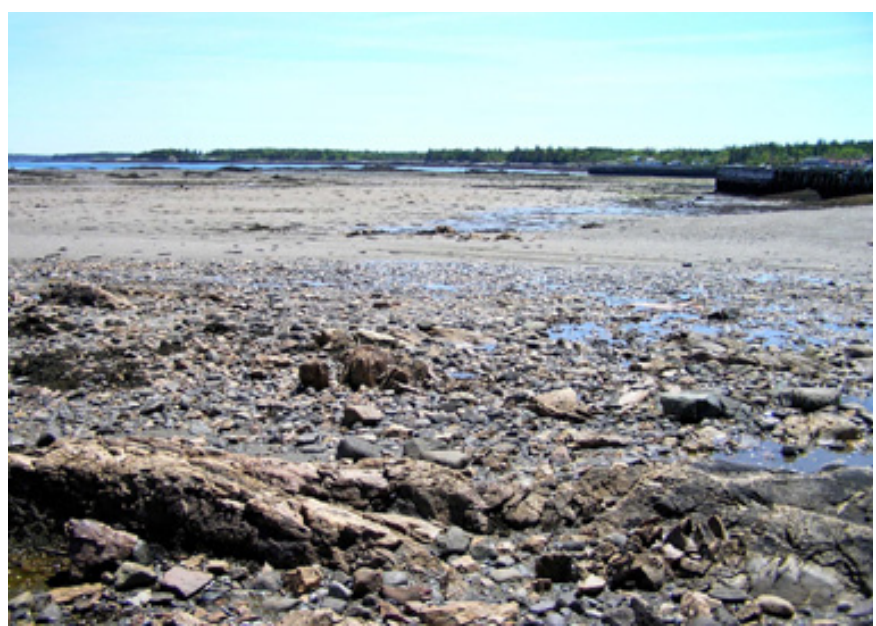

Fig. 13. View southward at low tide from the harbour at Woodwards Cove, across mainly meta-volcaniclastic ledges of Ingalls Head, Thoroughfare, and Priest Cove formations. Similar low elevations and small relief characterize most of the island east of the border fault.

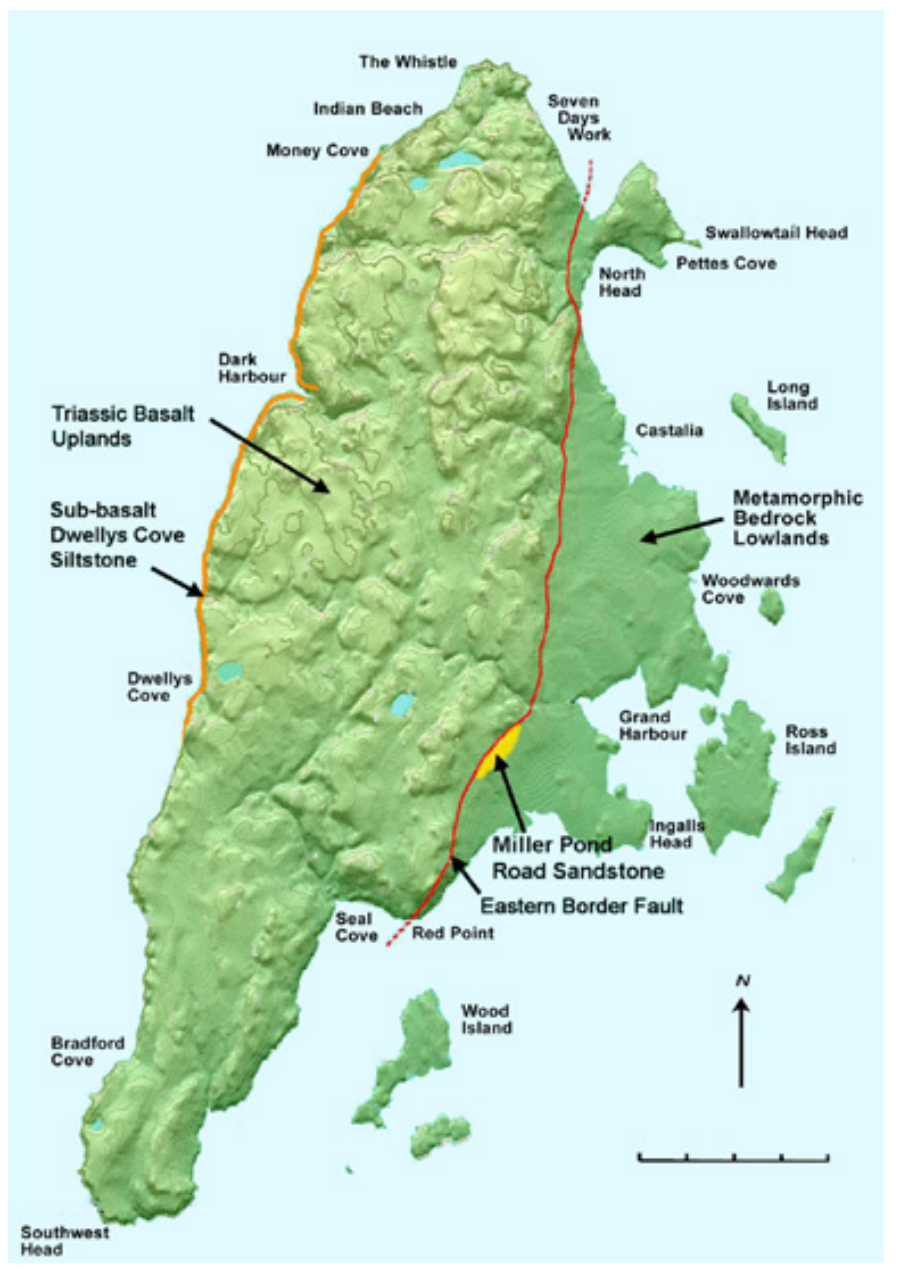

Fig. 14. Digital relief map of Grand Manan, showing the contrast in relief and topography on either side of the border fault. Base map source: Service New Brunswick (2010). 
Cretaceous (Roden-Tice and Wintsch 2002) led to erosion of the overlying strata. This ancient interface surface and Grand Manan Basin strata have remained relatively level since then, despite major tectonic activity that has tilted Mesozoic strata in other areas around the Bay of Fundy.

The model developed for the Grand Manan Basin includes the truncation of strata and basalt by post-deposition faulting, rather than thinning and on-lap with alluvial conglomerates against borders that were tectonically active before and during deposition. This interpretation conflicts with that of Wade et al. (1996) for the subsurface adjacent to the Grand Manan Fault on the eastern side of the White Head Island basement block (Fig. 1), in which basin strata become tilted and thinner against the fault border. The Grand Manan Basin must also move equally downward along its western border for the strata and basalt to maintain their original sub-horizontal orientations and thicknesses, as mapped across the island up to the Red Point border fault. The model by Wade et al. (1996) is consistent with a closed-basin interpretation, whereas the Grand Manan Basin observations indicate the former continuity of Triassic strata and basalts across areas between basins, followed by faulting and separation. Roden-Tice and Wintsch (2002) presented a similar model for the Hartford Basin and surrounding areas of southern Connecticut (USA), based on fission-track ages for Late Jurassic and Cretaceous uplift and tectonic tilting.

The two models might agree better for post-basalt features, in which alluvial breccias and basement-clast conglomerates were developed in Jurassic strata along some border faults according to tectonic action soon after the volcanism ( $\mathrm{McHone}$ and Puffer 2003). This process is indicated by paleo-talus along the northern end of the Fundy Basin (Olsen and Et-Touhami 2008), by regional tilting of all basin strata toward border faults, and by Jurassic border fanglomerates mapped in rift basins in eastern North America (Olsen 1997). Such features are missing at Grand Manan.

Another question is the assignment of the Miller Pond Road sandstone outcrop to the base of the Triassic stratigraphic section. Post-metamorphic sandstone interpreted to be Late Triassic is present in the Lepreau Formation on the coast of the New Brunswick mainland to the north of Grand Manan, but the nature of its contacts with surrounding metamorphic rocks of the Brookville terrane and its correlation with other Triassic rocks is not clear (McLeod et al. 1994; MacNaughton and Pickerill 2010). Olsen and Et-Touhami (2008, p. 10) described Permian fluvial sandstone formations between the Late Triassic strata and older basement rocks in the northern Fundy Basin, and they suggest that the Lepreau Formation is also of that age. If so, perhaps the Miller Brook Road sandstone is Permian as well.

The Lepreau Formation is heterogeneous and includes coarse conglomerates with a variety of clast lithologies (Nadon and Middleton 1984), whereas the Miller Pond Road sandstone has only small angular clasts of the underlying phyllite (although the exposure is very limited). The sandstone in the Lepreau Formation also appears to be more strongly cemented as compared in a brief field visit by the author. These differences encourage the interpretation of the Miller Pond Road as presented herein, but better comparative studies would be useful.

\section{SUMMARY}

1. The Grand Manan Basin is a small Early Mesozoic rift basin in southern-most New Brunswick and eastern-most Maine, which is structurally distinct from the Fundy Basin but with similar Triassic formations. Overlying Jurassic strata are not present.

2. The eastern border of the basin bisects the island of Grand Manan in a north-south direction and is exposed as a westdipping normal fault at Red Point. The western border is submerged near the coast of Maine, and it is interpreted as a fault with a similar displacement so that strata in the basin remain generally horizontal.

3. Dark Harbour Basalt covers most of the island and is comprised from top to bottom of the Ashburton Head, Seven Days Work, and Southwest Head members. The uppermost few meters of Dwellys Cove grey siltstone and red sandstone are exposed beneath and in contact with the basalt along the western shoreline.

4. A few meters of Late Triassic (?) Miller Pond Road red sandstone rest upon and merge into paleo-regolith of Late Neoproterozoic (Ediacaran) phyllite of the Ingalls Head Formation.

5. With the interpretation of uppermost and lowermost Triassic sub-basalt strata exposed west and east of the Red Point Fault, the fault displacement must equal the thickness of the sedimentary section of the basin. The best available estimate for this thickness is about $2950 \mathrm{~m}$, as found in an exploration well in the Fundy Basin nearby to the north.

\section{ACKNOWLEDGEMENTS}

Nancy McHone provided field assistance and much other help during numerous years for this project. The author appreciates field visits or discussions of Grand Manan geology with Sandra Barr, Jelle de Boer, Richard Grant, Leslie Fyffe, Dan Kontak, Paul Olsen, George Pajari, Anthony Philpotts, John Puffer, Peter Thompson, and Chris White. John Hubert and an anonymous reviewer made many helpful suggestions for the manuscript.

\section{REFERENCES}

Alcock, F.J. 1948. Grand Manan, New Brunswick. Geological Survey of Canada, Map 965A (with marginal notes), scale 1:63 360 .

Allaby, E. 1984. Grand Manan: Grand Harbour, Grand Manan Museum, New Brunswick, 64 p.

Barnhardt, W.A., Belknap, D.A., Kelley, A.R., Kelley, J.T., and Dickson, S.M. 1996. Surficial Geology of the Maine Inner 
Continental Shelf: Petit Manan Point to West Quoddy Head. Geologic Map No. 96-13 (with text), scale 1:100 000. URL $<$ http://www.maine.gov/doc/nrimc/mgs/pubs/online/ics/ ics-petit-manan-quoddy.pdf> January 2011.

Barr, S.M., Mortensen, J.K., White, C.E., and Friedman, R.M. 2010. Age and petrology of the Machias Seal Island quartz monzodiorite, the southernmost rocks in New Brunswick, Canada. Atlantic Geology, 46, pp. 155-172. doi: 10.4138/ atlgeol.2010.009

Black, R.S., Barr, S.M., Fyffe, L.R., and Miller, B.V. 2004. PreMesozoic rocks of Grand Manan Island, New Brunswick: Field relationships, new $\mathrm{U}-\mathrm{Pb}$ ages, and petrochemistry. In Geological investigations in New Brunswick for 2003. Edited by G.L. Martin. New Brunswick Department of Natural Resources; Minerals, Policy and Planning Division, Mineral Resource Report 2004-4, pp. 21-40.

Chapman, E.J. 1870. Report on the copper deposit of Grand Manan, Bay of Fundy: private consulting paper with plate, copy held by Geological Survey of Canada, Ottawa, $7 \mathrm{p}$.

Cirilli, S., Marzoli, A., Tanner, L., Bertrand, H., Buratti, N., Jourdan, F., Bellieni, G., Kontak, D., and Renne, P.R. 2009. Latest Triassic onset of the Central Atlantic Magmatic Province (CAMP) volcanism in the Fundy Basin (Nova Scotia): new stratigraphic constraints. Earth and Planetary Science Letters, 286, pp. 514-525. doi:10.1016/j.epsl.2009.07.021

Deenen, M.H.L., Ruhl, M., Bonis, N.R., Krijgsman, W., Kuerschner, W.M., Reitsma, M., and Van Bergen, M.J. 2010. A new chronology for the end-Triassic mass extinction. Earth and Planetary Science Letters, 291, pp.113-125. doi:10.1016/j.epsl.2010.01.003

Dickson, S.M., Kelley, J.T., and Barnhardt, W.A. 1994. Geomorphology and Sedimentary Framework of the Inner Continental Shelf of Downeast Maine. Augusta, Maine Geological Survey Open File Report 94-11, 55 p. URL <http:// www.maine.gov/doc/nrimc/mgs/pubs/online/marine-reports/94-11.pdf $>$ January 2011.

Fyffe, L.R., and Grant, R.H. 2001. Precambrian and Paleozoic geology of Grand Manan Island. In Guidebook to Field Trips in New Brunswick and Western Maine. Edited by D. Lentz and R. Pickerill. New England Intercollegiate Geological Conference, Fredericton, New Brunswick, Trip A-5, 13 p.

Fyffe, L.R., and Grant, R.H. 2005. Bedrock geology of Grand Manan Island (parts of NTS $21 \mathrm{~B} / 1 \mathrm{O}$ and B/15). New Brunswick, Department of Natural Resources and Minerals Division, Open File Map, Plate 2005-24, scale 1:50 000.

Fyffe, L.R., Grant, R.H., and McHone, J.G. 2011. Bedrock geology of Grand Manan Island (parts of NTS $21 \mathrm{~B} / 1 \mathrm{O}$ and B/15). New Brunswick, Department of Natural Resources, Lands, Minerals, and Petroleum Division, Open File Map, Plate 2011-14, scale 1:50 000.

Greenough,J.D. 1995. Mesozoic rocks. In Geology of the Appalachian-Caledonian orogen in Canada and Greenland, The Geology of North America. Edited by Williams, H. Geological Society of America, pp. 567-600.
Hart, J., and Pajari, G.E. 1988. Environmental Geology and Hydrogeological Review on Grand Manan and White Head islands. New Brunswick Department of Fisheries, Open-File Report with maps, $27 \mathrm{p}$.

Kontak, D.J. 2008. On the edge of CAMP: geology and volcanology of the Jurassic North Mountain Basalt, Nova Scotia. Lithos, 101, pp. 74-101. doi:10.1016/j.lithos.2007.07.013

MacNaughton, R.B., and Pickerill, R.K. 2010. A cautionary note on the use of invertebrate trace fossils for correlation in the Triassic-Jurassic Fundy Group. Atlantic Geology, 46, pp. 90-94.

McHone,J.G. 1996. Broad-terrane Jurassic flood basalts across northeastern North America. Geology, 24, pp. 319-322. doi:10.1130/0091-7613(1996)024<0319:BTJFBA >2.3.CO;2

McHone, J.G. 2001. Mesozoic geology of Grand Manan. In Guidebook to Field Trips in New Brunswick and Western Maine. Edited by D. Lentz and R. Pickerill. New England Intercollegiate Geological Conference, Fredericton, New Brunswick, Trip B-6, 16 p.

McHone, J.G., and Puffer, J.H. 2003. Flood basalt provinces of the Pangaean Atlantic rift: Regional extent and environmental significance. In The Great Rift Valleys of Pangaea in eastern North America, Vol. 1: Tectonics, Structure, and Volcanism. Edited by P.M. LeTourneau and P.E. Olsen. Columbia University Press, New York, New York, pp. 141-154.

McLeod, M.J., Johnson, S.C., and Ruitenberg, A.A. 1994. Geological map of southwestern New Brunswick. New Brunswick Department of Natural Resources and Energy, Mineral Resources, Map NR-5, scale 1:250 000.

Mertz, K.A., and Hubert, J. 1990. Cycles of sand-flat sandstone and playa-mudstone in the Triassic-Jurassic Blomidon red beds, Fundy rift basin, Nova Scotia: implications for tectonic and climatic controls. Canadian Journal of Earth Sciences, 27, pp. 442-451. doi:10.1139/e90-039

Miller, B.V., Barr, S.M., and Black, R.S. 2007. Neoproterozoic and Cambrian U-Pb (zircon) ages from Grand Manan Island, New Brunswick: implications for stratigraphy and northern Appalachian terrane correlations. Canadian Journal of Earth Sciences, 44, pp. 911-923. doi:10.1139/e06-132

Nadon, G.C., and Middleton, G.V. 1984. Tectonic control of Triassic sedimentation in southern New Brunswick: local and regional implications. Geology, 12, p. 619-622. doi:10.1130/0091-7613(1984)12<619:TCOTSI >2.0.CO;2

Olsen, P.E. 1997. Stratigraphic record of the early Mesozoic breakup of Pangea in the Laurasia-Gondwana rift system. Annual Reviews of Earth and Planetary Sciences, 25, pp. 337-401. doi:10.1146/annurev.earth.25.1.337

Olsen, P. E., and Et-Touhami, M. 2008. Field Trip 1: tropical to subtropical syntectonic sedimentation in the Permian to Jurassic Fundy rift basin, Atlantic Canada, in relation to the Moroccan conjugate margin. Central Atlantic Conjugate Margins Conference, Halifax, Nova Scotia, Canada, August 2008, $121 \mathrm{p}$.

Patrick, T.O.H. 1964. Exploration of Grand Manan Island for 
Keevil Mining Group Limited. Geophysical Engineering Surveys Ltd, New Brunswick Department of Natural Resources, Mineral Report of Work \# 470333, p. 17.

Pe-Piper, G., and Piper, D.J.W. 1999. Were Jurassic tholeiitic lavas originally widespread in southeastern Canada? A test of the broad terrane hypothesis. Canadian Journal of Earth Sciences, 36, pp. 1509-1516. doi:10.1139/e99-059

Philpotts, A.R., Carroll, M., and Hill, J.M. 1996. Crystal-mush compaction and the origin of pegmatitic segregation sheets in a thick flood-basalt flow in the Mesozoic Hartford basin, Connecticut. Journal of Petrology, 37, pp. 811-836. doi:10.1093/petrology/37.4.811

Powers, S. 1916. The Acadian Triassic. Journal of Geology, 16, pp. 1-26, 105-122, 254-268. doi:10.1086/622299

Roden-Tice, M.K., and Wintsch, R.P. 2002. Early Cretaceous normal faulting in southern New England: Evidence from apatite and zircon fission track ages. Journal of Geology, 110, pp. 159-178. doi:10.1086/338281

Roworth, E., and Signell, R.P. 1998. Construction of Digital Bathymetry for the Gulf of Maine. Coastal and Marine Geology Program, Woods Hole, Massachusetts (USA). U.S. Geological Survey, Open-File Report 98-801. URL <http:// pubs.usgs.gov/of/1998/of98-801/bathy/index.htm> January 2011.
Schaltegger, U., Guex, J., Bartolini, A., Schoene, B., and Ovtcharova, M. 2008. Precise U-Pb age constraints for end-Triassic mass extinction, its correlation to volcanism and Hettangian post-extinction recovery. Earth and Planetary Sciences Letters, 267, pp. 266-275. doi:10.1016/j.epsl.2007.11.031

Schoene, B., Crowley, J.L., Condon, D.J., Schmitz, M.D., and Bowring, S.A. 2006. Reassessing the uranium decay constants for geochronology using ID0TIMS U-Pb data. Geochimica et Cosmochimica Acta, 70, pp. 426-445. doi:10.1016/j. gca.2005.09.007

Service New Brunswick 2010. Digital Topographic Data Base, 1998 (DTDB). URL <http://www.snb.ca/gdam-igec/ e/2900e_1c_i.asp> January 2011.

Wade, J.A., and Jansa, L.F. 1994. Preliminary interpretation of sub-North Mountain Basalt strata, Dark Harbour, Grand Manan Island, New Brunswick. In Current Research 1994Part E. Geological Survey of Canada, pp. 227-231.

Wade, J.A., Brown, D.E., Traverse, A., and Fensome, R.A. 1996. The Triassic-Jurassic Fundy Basin, eastern Canada: regional setting, stratigraphy, and hydrocarbon potential. Atlantic Geology, 32, pp. 189-231.

Editorial responsibility Sandra M. Barr 